\title{
Monitoring of Noise Contour Mapping and Hearing Conservation Program of Rice Milling Workers in Griyan Karanganyar
}

\author{
Seviana Rinawati ${ }^{1 *}$, Siti Rachmawati ${ }^{2}$, Iwan Suryadi ${ }^{1}$, Prabang Setyono ${ }^{2}$, Hash $i$ Hawali \\ Abdul Matin ${ }^{2}$, Lia Kusumaningrum², Sapta Suhardono ${ }^{2}$ \\ ${ }^{1}$ Department of Company Hygiene and Occupational Health and Safety, School of Vocational, \\ Sebelas Maret University, Indonesia \\ ${ }^{2}$ Department of Environmental Science, Faculty of Mathematic and Natural Science, Sebelas Maret \\ University, Indonesia
}

\begin{abstract}
The use of production machines for a rice mill creates noise in the workplace, in addition to causing hearing loss and also disrupting work performance. So that the potential danger of noise at work must be controlled. The purpose of this study was to determine the noise mapping and implementation of a hearing conservation program in the Griyan Karanganyar rice mill. The research methods used in this paper is descriptive method describing research data in the form of noise map using the surfer 13 application and assessment of hearing conservation programs through the employee assessment form. The results of data collection in the thresher machine area $=110.15 \mathrm{dBA}$, in the skin crushing machine area $=$ 109.39 dBA, in the bleaching machine area $=107.97 \mathrm{dBA}$, in the sifting area $=85.56 \mathrm{dBA}$ and in the drying area $=80.53 \mathrm{dBA}$. All above Threshold Limited Value (TLV) except in the drying area. Overall stated that the Hearing Conservation Program (HCP) was declared unsuccessful from the worker's assessment of $40 \%$ agreeing and $60 \%$ disagreeing.
\end{abstract}

Keywords. noise contour mapping, hearing conservation program

\section{Introduction}

Every activity carried out always involves human factors, machinery, materials and the stages of the process that can cause the risk of danger with different levels of risk that allows accidents and diseases caused by work. The risk of accidents and diseases caused by work is caused by the presence of sources of danger originating from work activities in the workplace. Labor is a company asset that is very important in the production process, so efforts are needed so that the health and safety of the workforce is always safe. Generally in all workplaces there are always sources of danger. There is almost no workplace that is

\footnotetext{
* Corresponding author: seviana.er@gmail.com
} 
completely free from sources of danger. Control of hazard sources aims to reduce losses caused by accidents and occupational diseases [1].

Health problems due to noise can be grouped into, Auditory disorders such as decreased hearing, damage to the eardrum and auditory nerve system, Non auditory such as insomnia, stress, decreased concentration, difficulty communicating and disturbance of calm or comfort [2].

According to researh [3] the intensity of noise in the work environment will increase if there are more sources of noise in the workplace. The distance between the source of noise and labor also affects the level of intensity of the noise received. The intensity of noise received by labor will decrease if the distance from the noise source increases, and vice versa. This noisy work environment condition is certainly endangering the workforce because noise with high intensity can cause health problems, both hearing and psychological disorders which in turn can cause various kinds of psychosomatic diseases [4]. In an effort to protect the health of the workforce from the dangers of disturbances caused by noisy work environments, one of the efforts is by implementing a Hearing Conservation Program.

Suma'mur [2] classifies the noise impact into two, namely the auditory impact and the non-auditory impact. Auditory impact is directly related to auditory functions such as decreased hearing power of the workforce, while non-auditory impacts such as disrupted communication, safety threats, decreased work performance, fatigue and stress. Most of these have exceeded the TLV so that the noise must be controlled as well as possible in order to protect the hearing organs of the workforce. Efforts are made to protect against noise hazards by implementing a Hearing Conservation Program (HCP).

Preliminary observations obtained the results of noise intensity in the thresher machine area $=100 \mathrm{dBA}$, skin crushing machine area $=99 \mathrm{dBA}$, bleaching machine area $=98 \mathrm{dBA}$, sifting area $=88 \mathrm{dBA}$ and drying area $=79 \mathrm{dBA}$ and interviews with 5 workers, 3 workers experienced complaints communication breakdown. Based on the background of the problem can be formulated a problem regarding: How to monitor of noise contour mapping and Hearing Conservation Program (HCP) of rice milling workers in Griyan Karanganyar.

\section{Research Methods}

The research method used in this writing is the descriptive method of research that results in the form of a description of the state of the object of the study without providing a generally accepted conclusion [5]. The author gives an overview of the object being monitored regarding noise intensity and its control. The object of this research is noise intensity and hearing conservation program. The program is carried out with the following activities: noise monitoring, engineering and administrative noise control, audiometer evaluation, use of ear protection equipment, education, program evaluation and program evaluation [6]. The location of the activity of activity in Griyan Karanganyar rice milling, with the stages of implementation, namely: identification of potential noise hazards as measured by the Sound Level Meter. The results of the data collection are compared with the Regulation of the Minister of Manpower of the Republic of Indonesia Number 5 of 2018 concerning Occupational Health and Safety of the Work Environment [7] and noise mapping data are made which describe the relative location of all noise sampling points. A line connecting points in the work area that has the same noise level and making noise contour map using the surfer 13 application. According to the Ministry of Health's standards of noise referring to the Regulation of the Minister of Health of the Republic of Indonesia No.718 of 1987 concerning noise related to health [8], [9]. Then an assessment of the efforts of the Hearing Conservation Program (HCP) that can be carried out in rice mills through the value sheet filled by all permanent workers in rice mills totalling 26 people. 


\section{Results and Discussion}

This rice mill located in Griyan Colomadu Karanganyar is one of the complete rice mills in the production process. Rice mills do not operate during the harvest season only and during the harvest season the number of workers reaches 50 people but there are 26 regular working days. The stages of the rice milling process are: The dried grain is put into the grain skin crushing machine to separate the skin grain and the contents of the grain into PK rice. $\mathrm{PK}$ rice is put into a two-stage bleaching machine to produce high-quality rice. The next stage is that the rice is sieved to be cleaner then the rice is put in a sack for weighing and packing. Conditions from outside the rice mill have been heard from the production process room, especially in the thresher, skin-breaking and whitening machines. Workplaces where there are machines that operate almost all workers do activities there without using ear plug (PPE) because they feel accustomed to and disturbing comfort in working. Based on research that has been done, it is obtained the results of noise intensity measurements and control efforts, namely:

\subsection{Noise measurement and noise mapping results}

Noise intensity carried out in Griyan Karanganyar rice mill was measured using Sound Level Meter, observation and direct interviews with rice mill workers. The work duration is 8 hours/day and the results of noise intensity are shown in the following table.

Table 1. Noise intensity measurement results

\begin{tabular}{|c|c|c|c|}
\hline \multicolumn{2}{|l|}{ Measurement Location } & Measurement Results dBA & Equivalent Noise Level dBA \\
\hline Thresher Machine: & 1 & 109 & \\
\hline & 2 & 108 & \\
\hline & 3 & 110 & 110,15 \\
\hline & 4 & 113 & \\
\hline & 5 & 110 & \\
\hline & 6 & 109 & \\
\hline Crushing Machine: & 7 & 110 & 10030 \\
\hline & 8 & 110 & 10,3 \\
\hline & 9 & 109 & \\
\hline & 10 & 108 & \\
\hline & 11 & 110 & \\
\hline & 12 & 109 & \\
\hline Bleaching Machine: & 13 & 109 & \\
\hline & 14 & 110 & $10 /, 97$ \\
\hline & 15 & 109 & \\
\hline & 16 & 110 & \\
\hline & 17 & 100 & \\
\hline & 18 & 99 & \\
\hline Sifting Area: & 19 & 83 & 8557 \\
\hline & 20 & 89 & OJ,J \\
\hline & 21 & 86 & \\
\hline & 22 & 84 & \\
\hline & 23 & 83 & \\
\hline & 24 & 85 & \\
\hline Drying Area: & 25 & 80 & \\
\hline & 26 & 83 & 80,53 \\
\hline & 27 & 80 & \\
\hline & 28 & 80 & \\
\hline & 29 & 79 & \\
\hline & 30 & 80 & \\
\hline
\end{tabular}


Based on the results of table 1 measurements, it can be seen that the place that exceeds the TLV is the thresher area with the highest noise intensity of $115.39 \mathrm{dBA}$ and it is known that the place that does not exceed the TLV is the drying area of $80 \mathrm{dBA}$. Equivalent noise intensity calculation from 5 measurement points namely thresher machine area is 110.15 $\mathrm{dBA}$, in the skin crushing machine area is $109.39 \mathrm{dBA}$, in the bleaching machine area is $107.97 \mathrm{dBA}$, in the sifting area is $85.56 \mathrm{dBA}$ and in the area drying is $80.53 \mathrm{dBA}$, thus indicating that the noise intensity in an area that does not exceed the TLV is $80.53 \mathrm{~dB}$ in the drying area. Based on Permenaker No. 5 of 2018 concerning Occupational Health and Safety of the Work Environment which states that the Threshold Limited Value for the exposure of 8 hours per day or 40 hours in one week is $85 \mathrm{dBA}$ [7], which is not in accordance with the TLV is the area of thresher machines, skin crushing machines, bleaching machines and sifting areas.

Noise intensity 109 dBA based on Permenaker No. 5 of 2018 the value of the noise threshold limited value with a duration of exposure of 1.88 minutes per day, noise intensity of $107 \mathrm{dBA}$ with a length of exposure of 3.75 minutes per day [7]. But if workers wearing ear plugs can work in an area of 85 dBA noise intensity for 8 hours per day, because ear plugs can reduce sound intensity between 10-15 dBA [10] or Tri-SealTM Reusable ear plug types Silicone Ear Plugs can reduce noise by up to $25 \mathrm{dBA}$ [3].

The results of direct interviews with workers to determine workers' perceptions of potential noise hazards indicate that the noise from the production machines is quite disturbing to workers, such as: communication problems, dizziness and fatigue. The risk is higher because workers for 8 hours/day do not use Personal Protective Equipment (ear plug).

Noise mapping in Griyan Karanganyar rice mills using the surfer 13 software application and based on Permenaker No. 5 of 2018 and Permenkes No.718 in 1987 [7], [8]. The data performed shows the noise contour maps with their measurement locations marked with the $\mathrm{x}(\mathrm{m}), \mathrm{y}$ (m axis) and $\mathrm{z}(\mathrm{dBA})$ as contouring material for the program, with the following pictures:
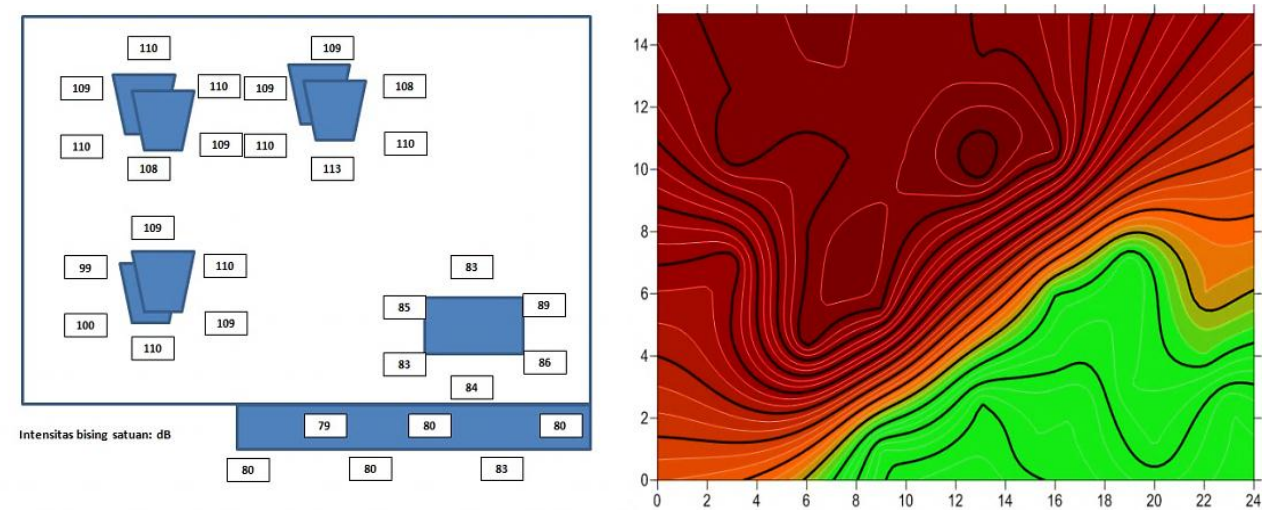

Fig. 1. Noise Contour Mapping

Information:

The form of factory area noise is presented in the following figure:

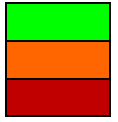

$$
\begin{aligned}
& :<85 \mathrm{dBA} \text { (safe area) } \\
& : 85-93 \mathrm{dBA} \text { (area required to use ear protection) } \\
& :>93 \mathrm{dBA} \text { (area required to use ear protection) }
\end{aligned}
$$

Based on fig. 1, the map results of the noise contour mapping in green areas are safe areas or areas under the TLV of noise, while the orange and red areas are more than of that. Noise in several work areas both in the orange and red areas consisting of production 
machines and sifting areas has the potential to have high noise in the surrounding area because there are no barriers. Workers who work without using ear plugs so that the intensity of noise that exceeds the TLV can cause health problems. This is in accordance with the statement of DP. Sasongko [11], stating that noise above TLV can cause various health problems for workers such as communication, psychological, physiological, balance (dizziness) and deafness.

Hearing loss due to noise is a hearing loss caused by exposure to loud noise over a long period of time and usually from a noisy work environment. Some things that accelerate someone's hearing loss due to noise, among others; high frequency, long exposure to noise, ototoxic treatment and others [12]. The main complaint of hearing loss can be: hearing loss / deafness (deaf), buzzing sound (tinnitus), pain in the ear.

As Dobie's theory [13] that the higher the intensity of sound exposure, the inner hair cells and supporting cells are also damaged. With the extent of damage to hair cells, degeneration can occur in the nerve which can also be found in the auditory nucleus in the brain stem. Continuously exposed to noise will cause deafness.

This is one of the risk factors for hearing loss, as explained by Habibi [14] explaining that if the exposure is longer and or the intensity is greater, a level of hearing loss will be achieved that cannot return to the normal hearing. The situation is called deafness due to noise (noise induced hearing loss) or permanent hearing threshold changes [15]. Similarly, research by Hardini et al [16] regarding the effects of machine noise on hearing impairment shows that workers who work at high noise intensity ( $>85 \mathrm{dBA}$ ) have a greater risk of hearing loss, compared to workers who work at low noise intensity $(<85 \mathrm{dBA})$. Also supported by Khoirul's research [17] with the results of research on factors affecting hearing loss in rice mill workers, stated the long exposure to noise is one of the factors that is significantly related to the incidence of hearing loss workers. Distribution pattern of noise mapping is done to find out the intensity distribution of areas that are the lowest and highest sources of noise. With the knowledge of areas that have the potential to cause noise can be carried out appropriate control.

\subsection{Control efforts: Hearing Conservation Program}

Noise control efforts in Griyan Karanganyar rice mills for workers who experience complaints of communication or hearing loss based on direct interviews of $61.5 \%$ of 26 workers. The control is in the form of a Hearing Conservation Program (HCP), namely:

a. This initial assessment is to get an idea of whether there is a noise hazard, through: measurement of noise intensity in the mill through the activities of the student interns / research as measurement data.

b. Evaluation of noise exposure, through: assessment of areas affected by noise due to the process and exposure of workers, rice mill owners make their own from the results of previous measurements or the results of research reports.

c. Engineering and Administrative Noise Control, engineering by muffling high noise engines through making a sandbox under the machine to reduce noise and vibration, covering rotating parts with plywood and marked, giving additional benches to make it easier for workers to enter rice into the mouth of the upper machine which height, adding a funnel to the top for removal of the remaining skin-crushing process. Whereas administratively by conducting socialization to workers related to machines and the impact on workers (but usually only once when entering work, or there is a new machine), rolling system / changing parts working in the area of thresher machines and skin crushing that have high noise with workers in sifting or drying area, providing lunch for workers but has not adjusted to the number of calories needed. 
d. Audiometric evaluation has not been done by the rice mill owner, only based on the results of a health check at the Puskesmas or hospital if the worker experiences health problems, especially hearing loss.

e. The use of personal protective equipment (ear plug), the ear plugs has been provided by the owner of the rice mill which was given at the beginning of the worker's work.

f. Worker training related to the use of ear plugs has been delivered at the beginning of the workforce accepted to work and delivered information on areas that are exposed to high noise, socialization related to occupational health and safety (OHS) from the local health center, no workers have been sent to attend OHS related training .

g. Recording and reporting related to the implementation of efforts to control the hearing conservation program has not been done by the rice mill owner, but noise intensity monitoring data already exists.

h. Program evaluation related to the success of the efforts made by the rice mill owner has not yet officially evaluated the program to be reported, but the results of the direct interview of the mill owner are able to provide an explanation related to the development of rice mill in conducting control efforts.

The results of the workers' assessment of the control efforts that have been made in the Griyan rice mill Karanganyar through filling the assessment form during the study show the following results:

Table 2. Results of the assessment of noise control efforts in rice mills

\begin{tabular}{lccc}
\hline \multicolumn{1}{c}{ Control Measures (HCP) } & \multicolumn{2}{c}{ Opinion of workers } & \multirow{2}{*}{ Control suitability } \\
& Yes & No & Fulfill \\
Initial assessment & $69 \%$ & $31 \%$ & Not yet fulfilled \\
Evaluation of noise exposure & $40 \%$ & $60 \%$ & Fulfill \\
Engineering and administrative controls & $80 \%$ & $20 \%$ & Not yet fulfilled \\
Audiometric evaluation & $10 \%$ & $90 \%$ & Not yet fulfilled \\
Use of PPE (ear plug) & $20 \%$ & $80 \%$ & Not yet fulfilled \\
Worker training & $7,6 \%$ & $92,4 \%$ & Not yet fulfilled \\
Recording and reporting & $7,6 \%$ & $92,4 \%$ & Not yet fulfilled \\
Program evaluation & $0 \%$ & $100 \%$ & $40 \%$ Fulfill \\
& \multicolumn{2}{c}{$100 \%$} & $60 \%$ Not yet fulfilled \\
\hline
\end{tabular}

The rice mill owner has tried to control to reduce noise, this is in accordance with Permenaker No. 5 of 2018 concerning Occupational Health and Safety of the Work Environment in article 7 paragraph 3 which reads "Control of the Work Environment as referred to in paragraph (1) and paragraph (2) shall be carried out in accordance with the control hierarchy including elimination, substitution, technical engineering, administration, and PPE provisions [7].

Hearing conservation programs that have been carried out by rice mills have not been fully met, but their implementation is in accordance with the guidelines on hearing conservation procedures listed in HJ Heinz OSH Standard, Subpart Number: G, Subpart Title: Occupational Health and Environmental Control, Standard Number: 5700.95, Standard Title: Occupational Noise Exposure. The activities covered by the program are basically the same as the hearing conservation program standards set by NIOSH [9], [18].

Control in the form of a Hearing Conservation Program (HCP), namely:

1. Initial assessment that has been carried out even though through a third party, namely an internship / research student and an assessment of workers by $69 \%$ agrees, this is in accordance with Permenaker No. 5 of 2018 article 2 saying "Entrepreneurs and / or administrators are required to carry out Environmental OHS requirements Work "and in Article 6 paragraph (3) which reads" In the event that the test method has not been 
stipulated in the Indonesian National Standard, the measurement can be carried out with other test methods in accordance with the standards that have been validated by the authorized agency "[7].

2. Evaluation of noise exposure, through the assessment of areas affected by noise due to processes exposed to workers and the assessment of workers $60 \%$ disagree, this is not in accordance with Permenaker No. 5 of 2018 article 10 (1) ie noise measurement and control must be carried out at the site work that has a source of noise hazard from the operation of work equipment[7].

3. Engineering and Administrative Noise Control, and supported by $80 \%$ assessment results so that it is in accordance with Permenaker No. 5 of 2018 article 10 (3) ie if the results of workplace measurements exceed the TLV must be controlled and in accordance with article 10 (4) of controls carried out by implementing a hearing loss prevention program[7].

4. Audiometric evaluation has not been done by the rice mill owner and the results of the assessment of workers $90 \%$ disagree, so this is not in accordance with Permenaker No. 5 of 2018 article 25, namely in the case of cases of occupational diseases caused by work environment factors, a control and handling program is carried out in accordance with the standards and provisions of the legislation[7]. And not in accordance with Law No. 36 of 2009 concerning Health article 12 reads "Everyone is obliged to maintain and improve the health status of others who are his responsibility"[19].

5. The use of personal protection equipment (ear plug) that has been provided by the mill owner given at the beginning of the worker, this complies with Law No. 1 of 1970 Chapter III concerning Requirements for Work Safety Article 3 paragraph 1 letter m concerning requirements for work safety to provide protection to workers[20]. and Permenakertrans No. 08 of 2010 article 2 paragraph 1 that "Employers must provide PPE for workers / laborers in the workplace" and paragraph 3 reads "PPE as referred to in paragraph (1) must be given by employers for free" but in practice PPE is not used when work[21]. and corroborated results of the assessment of workers $80 \%$ disagree.

6. Worker training related to occupational health and safety (OHS) efforts has not yet been carried out so that it is not in accordance with Permenakertrans No. 03 of 1982 concerning Workers' Health Services article 2 letter c which contains guidance on the work environment[22]. This statement is supported by the results of the assessment of 92.4\% workers who disagree.

7. Recording and reporting related to the hearing conservation program has not been done so it is not in accordance with Government Regulation on Occupational Health No. 88 of 2019 article 9 point d "Recording and reporting". Article 14 (1) recording and reporting of this hall can be seen from the results of the assessment of workers[23], namely $92.4 \%$ disagree.

8. Evaluation of program has not been carried out by rice mill owners and the assessment of workers $100 \%$ does not agree, the activities have not been in accordance with Government Regulation No. 50 of 2012 concerning SMK3 article 15 paragraph (1) "To ensure the suitability and effectiveness of the application of SMK3, employers must conduct a review" and paragraph (2) "The review is carried out on policies, planning, implementation, monitoring, and evaluation"[24].

Noise control efforts based on noise contour mapping are the application of hearing conservation programs, one of which: the use of ear plugs in locations that exceed threshold values according to color $=$ orange and red color zones. While the green zone is not required to wear ear plugs but because the production machines in one room and the sound of machines are influence each other so it advisable to use when entering the production area [25], [26]. 


\section{Conclusion}

Overall stated that the Hearing Conservation Program (HCP) was declared less successful in terms of the assessment of workers by $40 \%$ agreeing and $60 \%$ disagreeing. To achieve $100 \%$ HCP application, it is better for rice mills to carry out engineering in the thresher machine area, the area of the skin breaking machine and the area of the whitening machine such as the provision of barriers or barriers between the machine and the workers. which will occur, such as hearing loss, it is better if the provision of PPE (ear plug) should be provided and given free of charge to workers so that it is used as well as possible and avoid the danger of occupational diseases in the form of hearing loss. And safety signs should be installed in the work area to make workers aware of the dangers of noise exposure and increase discipline using PPE, so the safety sign should be placed in the right location to be easily visible and read by workers.

\section{References}

1. S.Shahab. Occupational Health and Safety Management Techniques. Jakarta : PT. Bina Sumber Daya Manusia (1997).

2. Suma'mur. PK. Hygiene Industry and Occupational Health. Jakarta: PT. Gunung Agung (2013).

3. B.Santoso. Noise Analysis in the Sugar Production Process at the Masakan Stasiun, Putaran, and Power House at Pg Bunga Mayang Lampung (2008).

4. Buchari. Group of Laws and Regulations of Occupational Health and Safety. Yogjakarta : Ergonomics, Occupational Health and Safety Service Hall (2007).

5. A.Taufiqurrahman. Medical and Health Research Methodology. Klaten: Indonesia's Community Sustainability Association (2003).

6. R.Ambar W. Hearing Conservation Program at Workplace, Cermin Dunia Kedokteran No 14. Jakarta. (2004).

7. Regulation of the Minister of Manpower of the Republic of Indonesia Number 5 of 2018 concerning Occupational Health and Safety at Work Environment (2018).

8. Regulation of the Minister of Health of the Republic of Indonesia No.718 of 1987 concerning noise related to health (1987).

9. National Institute for Occupational Safety and Health (NIOSH). Occupational Noise Exposure. Cincinnati-Usa (1998).

10. S.Budiono. Bunga Rampai of Occupational Health and Safety. Semarang : Universitas Diponegoro Publisher Agency (2003).

11. DP.Sasongko, et.all. Environmental Noise. Universitas Diponegoro Publisher Agency Semarang (2000).

12.S.Indro, H.Hendarto, and B.Jenny. Hearing Loss (Deaf). In: Textbook of Health Ear Nose Throat Head \& Neck Sixth Edition, editor Soepardi Arsyad, et.all. FKUI. Jakarta (2009).

13. Dobie. Noise induced hearing loss. in:Bailey BJ, Ed. Head and neck surgeryotolaryngology.Vol.8.Philadelphia: JB Lippincott Company .h.1782-91 (2011).

14. MH.Habibi. Relationship between Noise Exposure and Occurrences of Hearing Loss in Musicians. J Indon Med Assoc. Volum: 61, No: May,5 2011. (2011).

15. J. Munilson, et.all. Hearing loss due to noise: A review of several cases. Research J of the Andalas University School of Medicine, Padang (2011). 
16. H.Tjan, et.all. Noise Effects of Electronic Machines Against Hearing Function Disorders in Workers in Sario District, Manado City, North Sulawesi. Thesis Universitas Sam Ratulangi, Manado. (2012).

17. H.Khoirul. Factors associated with the occurrence of hearing loss in rice mill workers in Wiradesa Village, Pekalongan Regency in 2011. Thesis Universitas Negeri Semarang, Semarang. (2011).

18. T.Soemitra. Hearing Conservation Program. Bandung : FKM UI. (1997).

19. Law of the Republic of Indonesia Number 36 of 2009 concerning Health

20. Republic of Indonesia Law No. 1 of 1970 concerning Work Safety. (1970).

21. Minister of Manpower and Transmigration Regulation No.PER / 08 / MEN / VII of 2010 concerning Personal Protective Equipment. (2010).

22. Minister of Manpower and Transmigration Regulation No.PER.03 / MEN / 1982 Regarding Workers' Health Services. (1982).

23. Government Regulation No. 50 of 2012 concerning the Implementation of Occupational Health and Safety Management System. (2012).

24. Republic of Indonesia Government Regulation No. 88 of 2019 concerning Occupational Health. (2019).

25. The Indonesian Ministry of Health, Practical Guidelines for the Hearing Conservation Program. Jakarta: Occupational Health Center of the Indonesian Ministry of Health. (2004).

26. Al-Sihah : Public Health Science J. Vol 8, Nomor 2, Juli-Desember 2016 (121-129). (2016) 